- FINANSE I PRAWO FINANSOWE.

- Journal of Finance and Financial Law •

Grudzień/December 2017 • vol. 4(16): 23-35

\title{
ŚWIADOMOŚĆ UBEZPIECZENIOWA STUDENTÓW W ZAKRESIE UBEZPIECZENIA KREDYTU
}

\author{
Anna Piechota \\ Wydział Ekonomiczno-Socjologiczny \\ Uniwersytet Łódzki \\ Daria Marczewska \\ Wydział Ekonomiczno-Socjologiczny \\ Uniwersytet Łódzki
}

\begin{abstract}
Streszczenie
Ubezpieczenia kredytu są oferowane klientom korzystającym z produktu bankowego jakim jest kredyt. Ubezpieczenie kredytu jest specyficznym produktem ubezpieczeniowym oraz jednym z elementów współpracy bankowo-ubezpieczeniowej. Celem artykułu jest ocena poziomu świadomości studentów w zakresie ubezpieczenia kredytu na podstawie przeprowadzonego badania kwestionariuszowego oraz dostępnych wyników badań w przedmiotowym zakresie. Przeprowadzone wśród studentów badanie ankietowe wskazało na odmienne poglądy, niewielkie doświadczenia oraz niepełną wiedzę w zakresie ubezpieczenia kredytu wśród badanych studentów. Dostępne wyniki badań potwierdzają obserwacje w przeprowadzonym badaniu. Poziom świadomości ubezpieczeniowej powinien być podnoszonym m.in. przez edukację.
\end{abstract}

Słowa kluczowe: ubezpieczenie kredytu, bancassurance, kredyt bankowy.

JEL Class: G21, G22, E51. 


\section{WPROWADZENIE (O ŚWIADOMOŚCI UBEZPIECZENIOWEJ)}

Z kwestią świadomości ubezpieczeniowej można się spotkać w literaturze w kontekście jej opisu oraz analizy w odniesieniu do: jej poziomu w ujęciu ogólnym [Iwko i Iwko 2015: 89-114], zrozumienia celu i treści oferty konkretnego ubezpieczenia [Bac 2009: 4-11], czy lojalności klientów wobec zakładów ubezpieczeń [Grzebieniak 2008: 277-278]. Niezależnie jednak od przyczyny rozważań nad świadomością ubezpieczeniową wszyscy autorzy wskazują, iż jest to istotny element sprawnie funkcjonującego rynku ubezpieczeń, gdyż jej wysoki poziom pozwala na racjonalne korzystanie $\mathrm{z}$ oferty zakładów ubezpieczeń [Iwko i Iwko 2015: 89].

Czym zatem jest świadomość ubezpieczeniowa? W literaturze najczęściej można spotkać odniesienia do definicji/określeń czterech autorów. Pierwsza z nich, Szromnika określa świadomość ubezpieczeniową, jako „nabytą cechę indywidualną jednostki lub grupy społecznej, kształtowaną w procesie rozwoju osobowego zachodzącego w określonych warunkach środowiskowych" [Szromnik 2001: 32]. Druga zaproponowana przez Pazio i Formanowską definiuje ją, jako „określony, ale zmienny w czasie stan intelektualny jednostek i społeczeństwa, który wynika ze stopnia znajomości, zrozumienia oraz racjonalnego wartościowania faktów i zdarzeń zachodzących na rynku ubezpieczeniowym" [Pazio i Formanowska 2002: 42-43]. Sułkowska definiuje świadomość ubezpieczeniową, jako „odrębną wartość społeczną, kategorią złożoną, względnie stałą i jest jednym z podstawowych wyznaczników poziomu intelektualnego jednostek i grup społecznych" [Sułkowska 2013: 9-10]. Czwarta została sformułowana przez Szumlicza, który określił świadomość ubezpieczeniową, jako „wiedzę i umiejętności pozwalające racjonalnie skorzystać z ochrony ubezpieczeniowej, czyli w konsekwencji wykazać stosowaną przezorność ubezpieczeniową" [Szumlicz 2006: 21]. Ponadto określił najistotniejsze cechy świadomości ubezpieczeniowej, do których zaliczył kluczowe zakresy wiedzy i umiejętności, tj.: kategorie ryzyka, funkcję ochronną ubezpieczenia, wspólnotę ryzyka, ogólne warunki ubezpieczenia i doubezpieczenie.

Iwko i Iwko stwierdzają dodatkowo, iż na poziom świadomości ubezpieczeniowej wpływa wiele istotnych elementów, tj.: postrzeganie zagrożeń, znajomość dóbr i usług zaspokajających potrzeby bezpieczeństwa, znajomość zakładów ubezpieczeń, oferowanych przez nie produktów oraz warunków obsługi, znajomość praw i obowiązków ubezpieczonych, umiejętność oceny poziomu dotychczasowej konsumpcji usług ubezpieczeniowych w stosunku do rzeczywistych potrzeb, umiejętność oceny korzyści wynikających z ochrony ubezpieczeniowej i innych środków zaspokajających potrzebę bezpieczeństwa [Iwko i Iwko 2015: 90]. 
Biorąc pod uwagę powyższe należałoby stwierdzić, iż świadomość ubezpieczeniową $\mathrm{w}$ zakresie ubezpieczenia kredytu będzie cechować przede wszystkim zrozumienie istnienia zagrożenia ryzykiem niezdolności do spłaty kredytu, mogącym powodować stratę $\mathrm{w}$ zasobach kredytobiorcy oraz że ubezpieczenie kredytu stanowi niejako inwestycję $\mathrm{w}$ bezpieczeństwo materialne w sytuacji powstania straty w spodziewanych zasobach materialnych. Natomiast na poziom świadomości ubezpieczeniowej w zakresie ubezpieczenia kredytu ma wpływ wiele czynników, m.in.: znajomość ubezpieczenia kredytu, jako produktu ubezpieczeniowego i warunków jego obsługi, umiejętność oceny: poziomu dotychczasowej konsumpcji ubezpieczenia kredytu w stosunku do rzeczywistych potrzeb i korzyści wynikających z ochrony ubezpieczeniowej, jaką daje ubezpieczenie kredytu.

Celem artykułu jest ocena poziomu świadomości ubezpieczeniowej w zakresie ubezpieczenia kredytu w oparciu o dane dotyczące wiedzy, doświadczenia i opinii w oparciu o przeprowadzone badanie kwestionariuszowe oraz dostępne wyniki badań w przedmiotowym zakresie.

\section{CHARAKTERYSTYKA KREDYTU BANKOWEGO}

Bankowość pełni wyjątkową rolę w kształtowaniu się przebiegu mechanizmów gospodarczych. Bank jest instytucją komercyjną, której działalność skupia się głównie na przyjmowaniu depozytów oraz udzielaniu kredytów. Realizuje usługi związane $\mathrm{z}$ obrotem pieniężnym, a w ostatnich dziesięcioleciach usługi te dotyczą zróżnicowanych obszarów finansów [Law 2014: 36]. Funkcje działalności banku można podzielić na [Kosiński 2017: 12]: depozytowo-kredytową, rozliczeniową i inwestycyjną. Z perspektywy artykułu najważniejsza jest funkcja depozytowo-kredytowa polegająca na tym, że deponenci środków pieniężnych w zamian za ich oprocentowanie pozostawiają je do dyspozycji bankowi na określony czas. Deponenci chętnie powierzają swoje środki nie tylko ze względu na spodziewany zysk, ale również bezpieczeństwo operacji. Następnie bank angażuje te środki w działalność kredytową.

Umowa kredytu (uregulowana prawnie) stwierdza zobowiązanie banku (kredytodawcy) do przekazania środków pieniężnych do dyspozycji kredytobiorcy na określony czas i cel, i klienta (kredytobiorcy) do zwrotu wykorzystanej kwoty wraz z odsetkami i prowizją w wyznaczonym terminie [Ustawa $\mathrm{z}$ dnia 29 sierpnia 1997 r. Prawo Bankowe, Dz.U. nr 140, poz. 939, z późn. zm.]. Konsekwencją umowy kredytu jest generowanie tzw. ryzyka kredytowego zagrażającego bankowi, gdyż stawiając środki do dyspozycji kredytobiorcy przyjmuje on na siebie niebezpieczeństwo niespłacenia kredytu [Opolski 1997: 152]. Banki chcąc ograniczyć ryzyko kredytowe wykorzystują różne instrumenty, tj.: ocena 
zdolności kredytowej, monitoring kredytowy [Iwanowicz-Drozdowska 2010: 256], czy ustanawianie prawnych zabezpieczeń kredytów: osobistych i rzeczowych. Zabezpieczeniami osobistymi są np. weksel własny in blanco, poręczenie wekslowe, gwarancja bankowa, a rzeczowymi są m.in.: hipoteka, zastaw na zasadach ogólnych, bankowy zastaw rejestrowy, czy ubezpieczenie kredytu [Narodowy Bank Polski].

\section{ISTOTA UBEZPIECZENIA KREDYTU}

Ubezpieczenia kredytu są jednym z tzw. ubezpieczeń finansowych. Produkty te oferowane są przez zakłady ubezpieczeń działające w dziale II ustawowej klasyfikacji ubezpieczeń, zgodnie z którą wyróżnia się: ubezpieczenia kredytu, gwarancje ubezpieczeniowe oraz ubezpieczenia różnych ryzyk finansowych [Ustawa z dnia 11 września 2015 r. o działalności ubezpieczeniowej i reasekuracyjnej, Dz.U. 2015 poz. 1844]. Produkty te mogą być związane m.in. z wierzytelnościami finansowymi (ubezpieczenia kredytu: hipotecznego, gospodarczego, inwestycyjnego czy konsumpcyjnego) oraz wierzytelnościami handlowymi (np. ubezpieczenia kredytu kupieckiego).

Celem ubezpieczenia kredytu jest „pokrycie strat majątkowych, wywołanych u kredytodawców, z powodu nieotrzymania od kredytobiorców w sytuacjach określonych $\mathrm{w}$ umowie ubezpieczenia należności za udzielony kredyt" [Lisowski 2016: 382]. Zakresem ubezpieczenia jest objęte ryzyko ogólnej niewypłacalności kredytobiorcy będącego przedsiębiorcą oraz całkowitej lub częściowej utraty zdolności do spłaty kredytu przez kredytobiorcę będącego osobą fizyczną, gdy nastąpi jego śmierć lub potwierdzona orzeczeniem lekarskim trwała utrata zdrowia uniemożliwiająca dalsze zarobkowanie [Lisowski 2016: 394]. Suma ubezpieczenia odpowiada kwocie udzielonego kredytu wraz z odsetkami. Czas trwania ubezpieczenia zazwyczaj pokrywa się z okresem kredytowania. Składka w ubezpieczeniu kredytu zależna jest przede wszystkim od oceny ryzyka kredytobiorcy i odzwierciedlona zostaje stopą składki, a także wysokości kwoty kredytu oraz długości okresu kredytu. Wystąpienie wypadku ubezpieczeniowego, czyli potwierdzonej niezdolności do spłaty kredytu wywołanej ubezpieczonym zdarzeniem losowym rodzi podstawy do ubiegania się o odszkodowanie. Określona w umowie ubezpieczenia odpowiedzialność zakładu ubezpieczeń może dotyczyć pełnej kwoty ubezpieczonego kredytu lub jej części (np. kilku rat) [Lisowski 2016: 394-395].

Stronami ubezpieczenia są ubezpieczyciel (zakład ubezpieczeń) i ubezpieczający, którym może być bank (kredytodawca) lub klient (kredytobiorca) - osoba fizyczna lub prawna. W pierwszym przypadku umowa ubezpieczenia 
zawierana pomiędzy ubezpieczycielem a bankiem obejmuje grupę (portfel) udzielanych przez bank kredytów i ma charakter ubezpieczenia grupowego. W drugim zaś przypadku, umowa zawierana jest pomiędzy ubezpieczycielem a klientem (kredytobiorcą) i ma charakter ubezpieczenia indywidualnego. W obu przypadkach ubezpieczonym jest klient banku (kredytobiorca), jednakże zgodnie z zapisami umowy dokonywana jest cesja praw z ubezpieczenia na rzecz banku (kredytodawcy) [Ronka-Chmielowiec 2016: 133].

Do kanałów dystrybucji ubezpieczeń kredytu należy zaliczyć, poza kanałami bezpośrednimi (tj. pracowników etatowych zakładu ubezpieczeń), również pośrednie, w tym banki. Ścisła współpraca banków z zakładami ubezpieczeń (tzw. bancassurance ${ }^{1}$ ) sprzyja sprzedaży, po pierwsze - różnorodnych produktów ubezpieczeń przez banki, po drugie - produktów ubezpieczeniowych powiązanych z produktem bankowym. Realizacja drugiego typu sprzedaży powoduje, szczególnie w przypadku sprzedaży ubezpieczeń kredytu finalnie do zobowiązywania klienta (kredytobiorcę) do pokrycia kosztów ochrony ubezpieczeniowej banku przed ryzykiem kredytowym.

Z perspektywy klienta ubezpieczenie kredytu jest prostym sposobem na zabezpieczenie się przed ryzykiem związanym z zaciągniętym zobowiązaniem [Korenik 2007: 215-216], ale produkt ten nie jest jednoznaczny i prosty w swej konstrukcji. Ponadto niezależnie od sposobu/wariantu zawarcia ubezpieczenia stanowi ono ochronę przede wszystkim interesu banku, jako kredytodawcy i z jego punktu widzenia ubezpieczenie może stanowić korzystne zabezpieczenie spłaty kredytu. Co ważne, wywiązanie się ubezpieczyciela z obowiązku - spłaty (całkowitej lub częściowej) kredytu, nie skutkuje zniesieniem obowiązku kredytobiorcy. Opłacona bankowi kwota kredytu staje się wierzytelnością ubezpieczyciela i skutkuje regresem zakładu ubezpieczeń w stosunku do ubezpieczonego [Więcko 2009: 25-26].

${ }^{1}$ Pojęcie bancassurance zostało zdefiniowane przez Komisję Nadzoru Finansowego jako „oferowanie ubezpieczeń przez banki (pośrednictwo w zawieraniu umów ubezpieczenia lub oferowanie przystąpienia do umowy ubezpieczenia na cudzy rachunek) na podstawie umów zawartych pomiędzy bankiem a zakładem ubezpieczeń powiązane bezpośrednio z produktem bankowym oraz na niepowiązane bezpośrednio z produktem bankowym, a także ubezpieczeniowych produktów o charakterze inwestycyjnym lub oszczędnościowym. Przez bancassurance należy także rozumieć zawieranie przez bank umów ubezpieczenia, powiązanych $\mathrm{z}$ produktem bankowym, w przypadku których klient banku na podstawie odrębnej umowy zobowiązany jest pokryć koszty ochrony ubezpieczeniowej banku przed poszczególnymi rodzajami ryzyka objętymi tą umową ubezpieczenia" [Komisja Nadzoru Finansowego 2014]. 


\section{3. ŚWIADOMOŚĆ UBEZPIECZENIOWA W ZAKRESIE UBEZPIECZENIA KREDYTU W ŚWIETLE BADAŃ WŁASNYCH}

W celu poznania świadomości ubezpieczeniowej w zakresie ubezpieczenia kredytu zostało przeprowadzone pilotażowe badanie kwestionariuszowe, które objęło $264^{2}$ studentów studiów stacjonarnych stopnia pierwszego na kierunku Finanse i rachunkowość Wydziału Ekonomiczno-Socjologicznego Uniwersytetu Łódzkiego. Autorki przyjęły założenie, iż przyjęta grupa badawcza to osoby, które mogą już korzystać z kredytu bankowego i ubezpieczenia kredytu, lub być nim zainteresowane $\mathrm{w}$ pewnej perspektywie czasowej, bądź mogliby już być z nimi związani poprzez posiadanie kredytu bankowego lub ubezpieczenia kredytu przez bliskie im osoby.

Z pojęciem ubezpieczenia kredytu spotkało się aż 75\% badanych, a dla $11 \%$ było to pojęcie obce, pozostali nie mieli zdania w tej sprawie. Dla badanych oznacza ono przede wszystkim: „narzędzie zabezpieczające kredytobiorcę w niektórych sytuacjach” oraz ,zabezpieczenie banku przed zaprzestaniem spłaty rat przez kredytobiorcę”, ale również „ubezpieczenie wartości pieniądza przed spadkiem jego wartości” oraz „ubezpieczenie pożyczonych pieniędzy przed kradzieżą" (wykres 1). Ponad połowa badanych udzieliła poprawnych odpowiedzi (31\%), gdyż stwierdziło, że ubezpieczenie kredytu zabezpiecza kredytobiorcę w niektórych sytuacjach, $25 \%$ badanych za zasadną wybrali odpowiedź, że ubezpieczenie to ma na celu ochronę interesu banku. $\mathrm{Z}$ mniejszą intensywnością pojawiły się odpowiedzi niezgodne z pojęciem ubezpieczenia, niemożliwe jest ubezpieczenie pieniądza przed spadkiem wartości, jak uważa $12 \%$ badanych, ani ochronienie ich przed kradzieżą (6\%). Wnioskując, pojęcie ubezpieczenia kredytu jest dość dobrze znane studentom, a niewiedza może wynikać z nieodbycia jeszcze kursu przedmiotu Ubezpieczeń.

Badani uważają, iż przyczynami według których banki proponują ubezpieczenia kredytów są przede wszystkim: „zmniejszenie ryzyka spłaty kredytów udzielonych przez bank”, „chęć zarobienia przez banki na prowizji, którą otrzymują w zamian za zawarte umowy ubezpieczenia” oraz „chęć podniesienia atrakcyjności sprzedawanych kredytów (zawarcie umowy ubezpieczenia proponuje obniżenie oprocentowania)" (wykres 2).

${ }^{2}$ Edukacja na studiach stacjonarnych stopnia pierwszego na kierunku Finanse i rachunkowość Wydziału Ekonomiczno-Socjologicznego Uniwersytetu Łódzkiego w zakresie ubezpieczeń obejmuje przedmiot Ubezpieczenia w wymiarze 30 godzin (15 godzin i 15 godzin ćwiczeń). Dodatkowa wiedza dostępna studentom jest tylko na specjalności „Ubezpieczenia” oraz „Decyzje Finansowe". 


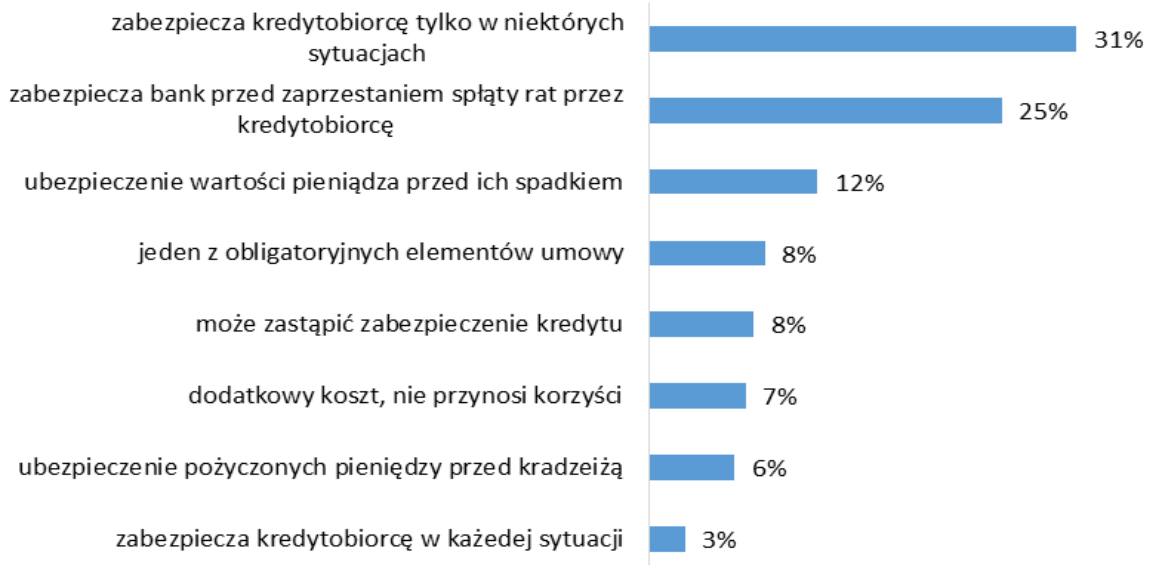

Wykres 1. Znaczenie ubezpieczenia kredytu

Źródło: opracowanie własne na podstawie przeprowadzonych badań.

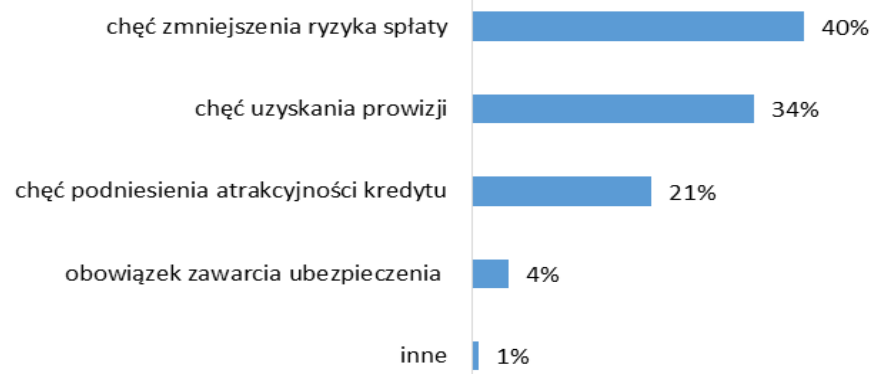

Wykres 2. Powody oferowania przez banki ubezpieczenia podczas zawierania umowy kredytu

Źródło: opracowanie własne na podstawie przeprowadzonych badań.

Według 40\% badanych ubezpieczenie kredytu ma za zadanie zmniejszyć ryzyko niedokonania spłaty długu przez kredytobiorcę. Ponad 1/3 uważała, że banki oferują produkty ubezpieczeniowe tylko w celu uzyskania prowizji, związki bancassurance niosą znacznie więcej korzyści zarówno dla banków jak i zakładów ubezpieczeń. Co piąty badany udzielił odpowiedzi, że podpisanie umowy ubezpieczenia spowoduje obniżenie oprocentowania kredytu, co jest prawdą, ponieważ ubezpieczenie pełni rolę dodatkowego zabezpieczenia. Wskazano również błędne odpowiedzi (4\%) związane z obowiązkiem zawarcia umo- 
wy ubezpieczenia. Niski odsetek błędnych odpowiedzi wskazuje na fundamentalną wiedzę badanych studentów w zakresie ubezpieczenia kredytu.

Wysoki odsetek badanych (41\%) uważał, iż zawarte (przez nich samych lub osoby im bliskie) umowy kredytu nie były ubezpieczone, a aż 34\% badanych nie miało w tym zakresie wiedzy. Posiadanie takiego ubezpieczenia potwierdziło $26 \%$ ankietowanych. W kontekście korzystania z ochrony ubezpieczeniowej $72 \%$ zapytanych nie wiedziało czy istnieje możliwość wyboru zakładu ubezpieczeń podczas podpisywania umowy ubezpieczeniowej. Połowa badanych osób nie wiedziała czy istnieje możliwość zapoznania się z ogólnymi warunkami ubezpieczenia przed podpisaniem umowy ubezpieczenia, a $20 \%$ nie byłaby w ogóle nimi zainteresowana. Wysoki odsetek badanych (65\%) nie wiedział czy na ratę kredytu wpływa zawarcie umowy ubezpieczenia kredytu, a $11 \%$ nie interesowała się, jakie są składowe rat (wykres 3). Uzyskane odpowiedzi wskazują na niedostateczną wiedzę $w$ tematyce zawierania umów kredytów i oferowanych wraz z nimi umów ubezpieczeniowych. Ponad $3 / 4$ ankietowanych stwierdziła, że nie miało możliwości wyboru zakładu ubezpieczeń podczas podpisywania umowy kredytu, a połowa nie była zainteresowana Ogólnymi Warunkami Ubezpieczenia oraz prawie $70 \%$ badanych nie interesuje się składowymi rat kredytu. Taki stan rzeczy może wynikać z faktu, że zjawisko zaciągnięcia kredytu dotyczyło bardzo małej próby spośród badanych osób.

\section{Czy według Pana/i ubezpieczenie kredytu jest niezbędne przy zaciąganiu kredytu? \\ Czy podczas podpisywania umowy kredytu miał Pan/i, Państwa bliscy możliwość dokonania wyboru zakładu ubezpieczeń? \\ Czy przed podpisaniem umowy ubezpieczenia kredytu zostały przedstawione Panu/i, Państwa bliskim Ogólne Warunki Ubezpieczenia? \\ Czy rata Pana/i, Państwa bliskich kredytu jest wyższa} z powodu zawarcia umowy ubezpieczenia?

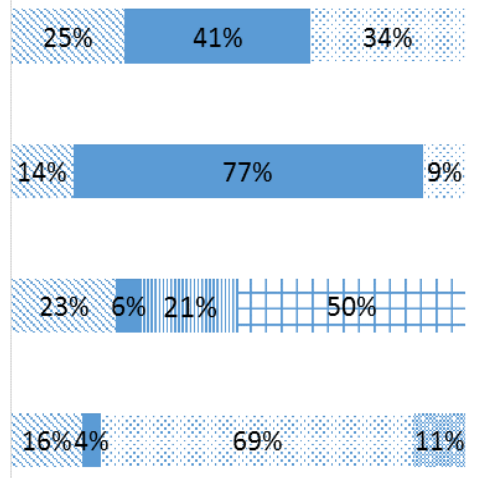

$1 \%$

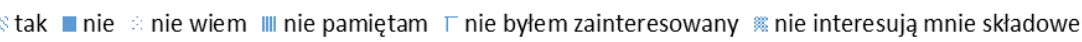

Wykres 3. Doświadczenie w zakresie ubezpieczenia kredytu wśród studentów

Źródło: opracowanie własne na podstawie przeprowadzonych badań. 


\section{4. ŚWIADOMOŚC UBEZPIECZENIOWA W ZAKRESIE UBEZPIECZENIA KREDYTU W ŚWIETLE DOSTĘPNYCH WYNIKÓW BADAŃ}

Dostępna literatura nie zawiera informacji dotyczących świadomości ubezpieczeniowej w zakresie ubezpieczeń kredytu. Istniejące wyniki badań, w tym przeprowadzonych na podobnej grupie badawczej, w zakresie świadomości ubezpieczeniowej mają charakter indywidualny, czyli wyrażają pogląd o samoświadomości ubezpieczeniowej [szerzej: Wieteska 2010]. Wynika z nich, że Polacy nie dysponują wystarczającą wiedzą w zakresie ubezpieczeń, nie tylko finansowych. Przed 2010 rokiem [Wieteska 2010: 236] 32\% Polaków deklarowało, że niewiele wie o ubezpieczeniach, $11 \%$ nie było zainteresowanych tą tematyką. Według badań przeprowadzonych w roku 2000 [Instytut ARC Rynek i opinia 2000: 78] przez Państwowy Urząd Nadzoru Ubezpieczeń tylko 6\% posiadało dobrą lub bardzo dobrą wiedzę o ubezpieczeniach.

Badanie przeprowadzone wśród studentów Uniwersytetu Mikołaja Kopernika w Toruniu wskazuje, iż duża część badanych nie czyta ogólnych warunków ubezpieczenia (odpowiednio 33,8\% i 25,4\% studentów I i IV roku studiów). Nie poznając dokładnie oferty nie jest możliwe dokonanie racjonalnego wyboru produktu ubezpieczeniowego. W opinii społeczeństwa zakłady ubezpieczeń stwarzają problemy z wypłatą odszkodowań (31\%), zaniżają prawdziwą wartość, a ich działania są powolne (45\%). Niewielu badanych osobiście uczestniczyło w likwidacji szkody ubezpieczeniowej, ale utożsamiają się z negatywną opinią społeczeństwa o ubezpieczeniach [Walczak i Żołądkiewicz 2011: 520-522].

Dalsze badania wskazują na brak zaufania do zakładów ubezpieczeń. Wyniki wskazały, iż $90 \%$ ankietowanych studentów ${ }^{3}$ liczyłoby na pomoc rodziny w sytuacji niezdolności do pracy, a jedynie 7\% szukałoby pomocy u zakładów ubezpieczeń, a $22 \%$ nie liczyłoby na nikogo. Respondenci największym zaufaniem darzyli banki (badani określając poziom zaufania od najmniejszego do największego wskazali odpowiednio: 1-7\%, 2-9\%, 3-29\%, 4-39\%, 5-16\%, co daje średnią na poziomie 3,49) [Majewski i Walczak 2013: 47-48]. Badanie z lat 2013-2014 wśród studentów uczelni publicznych w Poznaniu wskazało, iż rynek ubezpieczeń jest oceniony pozytywnie oraz na znajomość instytucji ubezpieczeniowych [Kałużny 2015: 120].

Badania przeprowadzone na terenie województwa dolnośląskiego [Iwko i Iwko 2015: 95-107], w których 28\% stanowili studenci, również wskazują na niski poziom wiedzy ubezpieczeniowej. Badani potrafili wymienić tylko dwa lub mniej zakładów ubezpieczeń $(20 \%)$, a $13 \%$ zna mniej niż dwa produkty

\footnotetext{
${ }^{3}$ Biorący udział w badaniu studenci pochodzili ze wszystkich wydziałów Uniwersytetu Mikołaja Kopernika w Toruniu i Bydgoszczy oraz dwóch wydziałów Wyższej Szkoły Bankowej w Toruniu i Bydgoszczy.
} 
ubezpieczeniowe. Część badanych (3\%) uznała, iż wiedza o ubezpieczeniach jest nieprzydatna. Niski poziom wiedzy ubezpieczeniowej zaobserwowano wśród $43 \%$ badanych, a wysoki tylko u 7\% badanych. Świadomość, jakie środki odwoławcze mogą zastosować podczas sporu z zakładem ubezpieczeń potwierdziło $15 \%$ respondentów.

W innym badaniu Turowska analizowała sprzedaż produktów ubezpieczeniowych przez banki. Respondenci nie znali pojęcia bancassurance, ale mieli wiedzę o posiadaniu przez banki pakietów ubezpieczeń. Wśród badanych tylko $25 \%$ skorzystała $\mathrm{z}$ oferty bancassurance, a przyczynami takiego wyboru było: „wymóg banku”, „propozycja złożona przez bank”, czy „wygoda”. Ponadto w każdej z badanych grup większość wskazywała, iż nie mieli wyboru firmy ubezpieczeniowej i została im on narzucona z góry [Turowska 2015: 4-8].

\section{PODSUMOWANIE}

Ubezpieczenie kredytu, na co wskazują wyniki badań, nie jest transparentnym dla klienta produktem. Klienci ubezpieczeń kredytu często nie mają wystarczającej wiedzy o szczegółach oferowanego produktu oraz nie wiedzą: czy oferowany produkt jest obowiązkowy, czy mają wpływ na wybór ubezpieczyciela, czy ochrona jest dopasowana do ich potrzeb, jak przebiega finansowanie [Rzecznik Ubezpieczonych 2007: 1-2]. Ubezpieczenie kredytu konsumenckiego oznacza zapewnienie zdolności dokonywania spłat kredytu przez zakład ubezpieczeń, chroni dłużnika przed takimi zdarzeniami jak choroba, urazy, niepełnosprawność, utrata pracy czy śmierć. W ujęciu mikroekonomicznym produkt ten może pomóc w utrzymaniu pozycji ekonomicznej, mimo wystąpienia szkody. W ujęciu makroekonomicznym wpływa na stabilny i równomierny sposób działania gospodarki narodowej. Fachowy zakład ubezpieczeń zaoferuje klientowi również dodatkowe usługi, np. odrębną ocenę kondycji finansowej. Te specyficzne usługi finansowe spełniają funkcję usługową, stymulacyjną i przeciwzatorową (płynnościową) [Lisowski 2016: 382]. Od dawna banki jako dodatkowe zabezpieczenie kredytu przyjmują cesję praw z umów ubezpieczenia na życie.

Sprzedaż ubezpieczeń kredytu przez banki ma swoje przesłanki efektywnościowe oraz marketingowe (obniżenie kosztów dystrybucji, wykorzystania efektu skali, wzajemne korzystanie z baz klientów) [Monkiewicz 2010: 349]. Korzyści współpracy mają obie instytucje i należy się podziewać jej dalszego rozwoju. Konsumenci, którzy mają (na co wskazuje przeprowadzone badanie) lub nie, styczności z zagadnieniami dotyczącymi bankowości czy ubezpieczeń mogą mieć problem ze zrozumieniem ubezpieczenia kredytu. Brak wiedzy i negatywne doświadczenia na rynku ubezpieczeniowym mogą prowadzić do niskiego poziomu zaufania do instytucji ubezpieczających. W opinii autorek konsumenci 
powinni posiadać właściwą na ich temat wiedzę, dobrze poznać usługi rynku finansowego, aby następnie móc z nich korzystać nie narażając się na negatywne skutki. Rynek bankowo-ubezpieczeniowy nie będzie mógł prawidłowo funkcjonować jeśli klienci (kredytobiorcy) jako podmioty rynku nie będą posiadali odpowiedniej wiedzy. Negatywne nastawienie polskiego społeczeństwa do zakładów ubezpieczeń, mimo braku znajomości zasad jego funkcjonowania, jest istotną barierą jego rozwoju. Wynikająca stąd potrzeba edukacji powinna być współrealizowana przez możliwie najszerszą grupę podmiotów (tzw. otoczenie konsumenta), przede wszystkim przez banki i zakłady ubezpieczeń - kluczowych współtwórców produktu i występujących ,wspólnie” jako oferenci produktów. Inne instytucje mogące wesprzeć proces edukacyjny to instytucje pełniące funkcje nadzoru (Komisja Nadzoru Finansowego), czy reprezentujące klienta (Rzecznik Finansowy) na rynku finansowym.

\section{BIBLIOGRAFIA}

Bac M., 2009, Świadomość ubezpieczeniowa posiadaczy nieruchomości w świetle badań ankietowych, „Świat Nieruchomości”, nr 3(69).

Grzebieniak A., 2008, Świadomość ubezpieczeniowa konsumenta jako warunek lojalności wobec zaktadu ubezpieczeń, „Studia Gdańskie”, t. V, Gdańsk.

Hadyniak B., 2014, Ubezpieczenia prywatne. Kompendium, Poltex, Warszawa.

Handschke J., Monkiewicz J., 2010, Ubezpieczenia. Podręcznik akademicki, Poltext, Warszawa.

Iwanowicz-Drozdowska M., Jaworski W.L., Zawadzka Z., 2010, Bankowość. Zagadnienia Podstawowe, Poltext, Warszawa.

Iwko J., Iwko J., 2015, Świadomość ubezpieczeniowa indywidualnych klientów zakladów ubezpieczeń z terenu województwa dolnośląskiego na tle badań ankietowych, „Rozprawy ubezpieczeniowe", $\mathrm{nr} 19$.

Kałużny J., 2015, Determinanty świadomości ubezpieczeniowej studentów poznańskich uczelni publicznych, „Rozprawy ubezpieczeniowe”, nr 19.

Komisja Nadzoru Finansowego, 2014, Rekomendacja U dotyczaca dobrych praktyk $w$ zakresie bancassurance, Warszawa, https://www.knf.gov.pl/Images/Rekomendacja_U_tcm75-38338.pdf [dostęp: 11.05.2017].

Komisja Nadzoru Finansowego, Biuletyn Roczny. Rynek ubezpieczeń 2015, Część V-Sprawozdanie statystyczne KNF-02, https://www.knf.gov.pl/opracowania/rynek_ubezpieczen/Dane_o_ rynku/Dane_roczne/dzne_roczne.html [dostęp: 04.05.2017].

Komisja Nadzoru Finansowego, Biuletyn Roczny. Rynek ubezpieczeń 2014, Część V-Sprawozdanie statystyczne KNF-02, https://www.knf.gov.pl/opracowania/rynek_ubezpieczen/Dane_o_ rynku/Dane_roczne/dzne_roczne.html [dostęp: 04.05.2017].

Komisja Nadzoru Finansowego, Biuletyn Roczny. Rynek ubezpieczeń 2013, Część V-Sprawozdanie statystyczne KNF-02, https://www.knf.gov.pl/opracowania/rynek_ubezpieczen/Dane_o_ rynku/Dane_roczne/dzne_roczne.html [dostęp: 04.05.2017].

Korenik D. (red.), 2007, Innowacyjne ustugi banku, Wydawnictwo Naukowe PWN, Warszawa.

Kosiński B., 2017, Podstawy wspótczesnej bankowości, PWE, Warszawa.

Law J. (red.), 2014, A Dictionary of Finance and Banking, OUP Oxford, Oxford. 
Lisowski J., 2016, Ubezpieczenia finansowe, [w:] W. Ronka-Chmielowiec, Ubezpieczenia, C. H. Beck, Warszawa.

Majewski P., Walczak D., 2013, Świadomość ubezpieczeniowa studentów w aspekcie postrzegania rynku ubezpieczeniowego, „Studia Oeconomica Posnaniensia”, no. 11.

Narodowy Bank Polski, https://www.nbportal.pl/slownik/pozycje-slownika/zabezpieczeniekredytu [dostęp: 04.05.2017].

Opolski K. (red.), 1997, ABC Bankowości. Samodzielny pracownik bankowy, Instytut Naukowo-Wydawniczy OLYMPUS CEiRB, Warszawa.

Pazio N.M., Formanowska A., 2002, Struktura świadomości ubezpieczeniowej w świetle badań, „Wiadomości Ubezpieczeniowe”, $\mathrm{nr}$ 3/4.

PUNU, 2000, Co Polacy wiedza i myśla o ubezpieczeniach?, Wyniki badań przeprowadzonych na zlecenie PUNU przez Instytut ARC Rynek i opinia, „Prawo. Ubezpieczenia. Reasekuracja”, nr 7-8.

Ronka-Chmielowiec W. (red.), 2016, Ubezpieczenia, C.H. Beck, Warszawa.

Rzecznik Ubezpieczonych, 2007, Podstawowe problemy bancassurance w Polsce - raport Rzecznika Ubezpieczonych, Warszawa.

Sułkowska W., 2013, Świadomość społeczna w obszarze ubezpieczeń społecznych w świetle badań naukowych", [w:] Upowszechnianie wiedzy i edukacja w zakresie ubezpieczeń społecznych, Zakład Ubezpieczeń Społecznych, Kraków.

Swiss Re., 2007, Bancassurance. Emerging Trends, Opportunities and Challenges, Wyd. „Sigma", no 5 .

Szromnik A., 2001, Rynek ubezpieczeniowy. Społeczne problemy kształtowania i funkcjonowania, Wydawnictwo Akademii Ekonomicznej w Krakowie, Kraków.

Szylak M., Zarębska A., 2014, Bancassurance - wspótpraca banków z zakładami ubezpieczeń, [w:] Sektor bankowy i ubezpieczeniowy w Polsce w dobie niestabilności. Wybrane problemy, Wydawnictwo Uniwersytetu Marii Curie-Skłodowskiej, Lublin.

Turowska A., Marciniak M., 2015, Bancassurance - produkt pożądanych przez Polaków?, „Studenckie Czasopismo Naukowe", nr 1, Wyższa Szkoła Bankowa w Toruniu.

Ustawa z 11 września 2015 r. o działalności ubezpieczeniowej i reasekuracyjnej, Dz.U. 2015, poz. 1844.

Ustawa z 29 sierpnia 1997 r. Prawo Bankowe, Dz.U. 1997, nr 140, poz. 939.

Walczak D., Żołądkiewicz A., 2011, Świadomość ubezpieczeniowa oraz skłonność do ryzyka studentów, „Prace Naukowe Uniwersytetu Ekonomicznego we Wrocławiu”, nr 228.

Wieteska S., 2010, Świadomość czy samoświadomość ubezpieczonych, „Annales. Etyka w życiu gospodarczym", nr 1.

Więcko M., 2009, Umowa ubezpieczenia jako zabezpieczenie wierzytelności banku - analiza podstaw prawnych, teorii i praktyki, „Rozprawy Ubezpieczeniowe”, $\mathrm{nr} 7$. 


\title{
EXPERIENCE, KNOWLEDGE AND OPINIONS AMONG STUDENTS ABOUT CREDIT INSURANCE
}

\begin{abstract}
Credit insurance is offered to customers using bank credit. This unique insurance product is also one of the elements of bancassurance, which involves partnerships between banks and insurance companies. The purpose of this article is to identify students' awareness of credit insurance and compare the results with other studies. Based on our survey of students, opinions about credit insurance differ and the knowledge of it is insufficient, which the authors believe underlines the need for relevant education.
\end{abstract}

Keywords: credit insurance, bancassurance, bank credit. 